\title{
BIOLOGICAL INTEGRITY OF SULLIVAN CREEK AND SKYLAND CREEK IN THE UPPER FLATHEAD RIVER TMDL PLANNING AREA BASED ON THE STRUCTURE AND COMPOSITION OF THE BENTHIC ALGAE COMMUNITY
}

\author{
Prepared for: \\ State of Montana \\ Department of Environmental Quality \\ P.O. Box 200901 \\ Helena, Montana 59620-0901 \\ Project Officer: Rosic Sada \\ DEQ Contract No. 200012-8
}

STATE COCUMENTS COLLECTIOH

$$
\cdots: 2.9903
$$

MONTANA STIATE LIBRARY

1515 E. 6th AVE.

HELENA. MMN'ITANA 595:0

\author{
Prepared by: \\ Loren L. Bahls, Ph.D. \\ Hannaea \\ 1032 Twelfth Avenue \\ Helena, Montana 59601
}

May 16, 2003 
.

- 


\section{Summary}

In August 2002, periphyton samples were collected from 2 sites on Sullivan Creek and 1 site on Skyland Creek in the upper Flathead River TMDL planning area in northwestern Montana for the purpose of assessing whether these streams are water-quality limited and in need of TMDLs. The samples were collected following MDEQ standard operating procedures, processed and analyzed using standard methods for periphyton, and evaluated following modified USEPA rapid bioassessment protocols for wadeable streams.

Hydrurus foetidus was the most abundant alga at all three sites. This cold-water stenotherm thrives in flashy mountain streams that have unstable channels and exhibit wide seasonal fluctuations in flow, temperature, and turbidity. H. foetidus, a chrysophyte, grows best in full sunlight and achieves maximum standing crop in winter and spring when flows are stable and turbidity is low.

Sullivan Creek above Connor Creek was subject to major environmental stresses that were natural in origin. The cold-water stenotherm and pollution-sensitive diatom Hannaea arcus accounted for over $80 \%$ of the diatom assemblage at this site. Although diatom species richness, equitability, and diversity were very low, values for the pollution index, sedimentation index, and percent abnormal cells indicated excellent water quality at this site. The stresses detected here were probably due to cold temperatures, low nutrient concentrations, steep gradients, and/or fast current velocities.

A significant increase in organic loading was detected at the site on Sullivan Creek below Quintonkon Creek, resulting in minor impairment. The dominant diatom species here was Fragilaria vaucheriae, a species that is somewhat tolerant of organic pollution. Modal categories for diatom ecological attributes indicate reduced availability of dissolved oxygen at this site and an increase in both organic and inorganic nutrients.

Diatom metrics indicate even greater organic loading in Skyland Creek above Bear Creek, resulting in moderate impairment. Encyonema silesiacum, a pollution-tolerant diatom, accounted for over half the diatom cells counted at this site. Most diatoms here exert only a moderate demand for dissolved oxygen, as compared to a continuously high demand at the two sites on Sullivan Creek. The modal category for saprobity at the Skyland Creek site was alphamesosaprobous, which is the same modal category as the lower site on Sullivan Creek and indicates waters with $25-70 \%$ oxygen saturation and $4-13 \mathrm{mg} / \mathrm{L}$ BOD. 


\section{Introduction}

This report evaluates the biological integrity ${ }^{1}$, support of aquatic life uses, and probable causes of stress or impairment to aquatic communities in Sullivan Creek and Skyland Creek in the upper Flathead River TMDL planning area in northwestern Montana. The purpose of this report is to provide information that will help the State of Montana determine whether Sullivan Creek and Skyland Creek are water-quality limited and in need of TMDLs.

The federal Clean Water Act directs states to develop water pollution control plans (Total Maximum Daily Loads or TMDLs) that set limits on pollution loading to water-quality limited waters. Water-quality limited waters are lakes and stream segments that do not meet waterquality standards, that is, that do not fully support their beneficial uses. The Clean Water Act and USEPA regulations require each state to (1) identify waters that are water-quality limited, (2) prioritize and target waters for TMDLs, and (3) develop TMDL plans to attain and maintain water-quality standards for all water-quality limited waters.

Evaluation of aquatic life use support in this report is based on the species composition and structure of periphyton (aka benthic algae, phytobenthos) communities at three sites that were sampled in August of 2002. Periphyton is a diverse assortment of simple photosynthetic organisms called algae that live attached to or in close proximity of the stream bottom. Some algae form long filaments or large gelatinous colonies that are conspicuous to the unaided eye. But most algae, including the ubiquitous diatoms, can be seen and identified only with the aid of a microscope. The periphyton community is a basic biological component of all aquatic ecosystems. Periphyton accounts for much of the primary production and biological diversity in Montana streams (Bahls et al. 1992). Plafkin et al. (1989) and Barbour et al. (1999) list several advantages of using periphyton in biological assessments.

\footnotetext{
'Biological integrity is defined as "the ability of an aquatic ecosystem to support and maintain a balanced, integrated, adaptive community of organisms having a species composition, diversity, and functional organization comparable to that of natural habitats within a region" (Karr and Dudley 1981).
} 


\section{Project Area and Sampling Sites}

The project area is located within Level IV ecoregion 4lc (Western Canadian Rockies), which is an extension of the Canadian Rockies Ecoregion in Flathead County, Montana (Woods et al. 1999). This is a high, rugged, glaciated region that lies west of the Continental Divide and is affected by moist Pacific maritime air masses. The Western Canadian Rockies are underlain by Precambrian rocks, including argillites and quartzites, and mantled by volcanic ash, glacial drift, and colluvium. Soils are thin or absent on upper mountain slopes but become deeper and more developed below. Climax vegetation consists of Douglas-fir, subalpine fir, grand fir, and Engelmann spruce forests, with alpine tundra on the highest peaks. The main land uses are logging, recreation, and wildlife habitat.

Periphyton samples were collected at two sites on Sullivan Creek and one site on Skyland Creek (Table 1). Sullivan Creek is a west side tributary of Hungry Horse Reservoir in the South Fork Flathead River hydrologic unit (USGS HUC 17010209). Skyland Creek, a tributary of Bear Creek, rises on the west side of the Continental Divide near Marias Pass in the Middle Fork Flathead River hydrologic unit (USGS HUC 17010207). The South Fork, Middle Fork, and North Fork meet to form the Flathead River near West Glacier, Montana. Sullivan Creek and Skyland Creek are classified B-1 in the Montana Surface Water Quality Standards.

\section{Methods}

Periphyton samples were collected following standard operating procedures of the MDEQ Planning, Prevention, and Assistance Division. Using appropriate tools, microalgae were scraped, brushed, or sucked from natural substrates in proportion to the importance of those substrates at each study site. Macroalgae were picked by hand in proportion to their abundance at the site. All collections of microalgae and macroalgae were pooled into a common container and preserved with Lugol's (IKI) solution.

The samples were examined to estimate the relative abundance and rank by biovolume of diatoms and genera of soft (non-diatom) algae according to the method described in Bahls 
(1993). Soft algae were identified using Smith (1950), Prescott (1962, 1978), John et al. (2002), and Wehr and Sheath (2003). These books also served as references on the ecology of the soft algae, along with Palmer $(1969,1977)$.

After the identification of soft algae, the raw periphyton samples were cleaned of organic matter using sulfuric acid, potassium dichromate, and hydrogen peroxide. Then permanent diatom slides were prepared using Naphrax, a high refractive index mounting medium, following Standard Methods for the Examination of Water and Wastewater (APHA 1998). At least 400 diatom cells ( 800 valves) were counted at random and identified to species. The following were the main taxonomic references for the diatoms: Krammer and Lange-Bertalot 1986, 1988, 1991 a, 1991b; Lange-Bertalot 1993, 2001; Krammer 1997a, 1997b, 2002; Reichardt 1997, 1999. Diatom naming conventions followed those adopted by the Academy of Natural Sciences for USGS NAWQA samples (Morales and Potapova 2000) as updated in 2003 (Dr. Eduardo Morales, Academy of Natural Sciences, digital communication). Van Dam et al. (1994) was the main ecological reference for the diatoms.

The diatom proportional counts were used to generate an array of diatom association metrics. A metric is a characteristic of the biota that changes in some predictable way with increased human influence (Barbour et al. 1999). Diatoms are particularly useful in generating metrics because there is a wealth of information available in the literature regarding the pollution tolerances and water quality preferences of common diatom species (e.g., Lowe 1974, Beaver 1981, Lange-Bertalot 1996, Van Dam et al. 1994).

Values for selected metrics were compared to biocriteria (numeric thresholds) developed for streams in the Rocky Mountain ecoregions of Montana (Table 2). These criteria are based on metric values measured in least-impaired reference streams (Bahls et al. 1992) and metric values measured in streams that are known to be impaired by various sources and causes of pollution (Bahls 1993). The criteria in Table 2 are valid only for samples collected during the summer field season (June 21-September 21) and distinguish among four levels of stress or impairment and three levels of aquatic life use support: (1) no impairment or only minor impairment (full support); (2) moderate impairment (partial support); and (3) severe impairment (nonsupport). 
These impairment levels correspond to excellent, good, fair, and poor biological integrity, respectively. In cold, high-gradient mountain streams, natural stressors will often mimic the effects of man-caused impairment on some metric values.

\section{Quality Assurance}

Several steps were taken to assure that the study results are accurate and reproducible. Upon receipt of the samples, station and sample attribute data were recorded in the Montana Diatom Database and the samples were assigned a unique number, e.g., 2655-01. The first part of this number (2655) designates the sampling site (Sullivan Creek above Connor Creek) and the second part (01) designates the number of periphyton samples that that have been collected at this site for which data have been entered into the Montana Diatom Database.

Sample observations and analyses of soft (non-diatom) algae were recorded in a lab notebook along with information on the sample label. A portion of the raw sample was used to make duplicate diatom slides. The slide used for the diatom proportional count will be deposited in the Montana Diatom Collection at the University of Montana Herbarium in Missoula. The duplicate slide will be retained by Hannaea in Helena. Diatom proportional counts have been entered into the Montana Diatom Database.

\section{Results and Discussion}

Results are presented in Tables 3, 4 and 5, which are located near the end of this report following the references section. Copies of aquatic plant field sheets are included in Appendix A. Appendix B contains a diatom report for each sample. Each diatom report includes an alphabetical list of diatom species in that sample and their percent abundances, and values for 65 different diatom metrics and ecological attributes. 


\section{Sample Notes}

Sullivan Creek above Connor Creek. This sample was sparse and the entire sample was oxidized to make the diatom slides. The Phormidium sp. in this sample occurred as an epiphyte on Hydrurus foetidus. Hannaea arcus was visually the dominant diatom in this sample.

Sullivan Creek below Quintonkon Creek. This sample was heavier than the one collected upstream. Hannaea arcus was the visual dominant among the diatoms in this sample.

Skyland Creek above Bear Creek. This sample was poorly preserved and in the process of decomposing. It was black and smelled strongly of hydrogen sulfide. The visually dominant diatoms in this sample were Encyonema silesiacum and Hannaea arcus.

\section{Non-Diatom Algae (Table 3)}

Hydrurus foetidus ranked first in biovolume in samples from all three sites (Table 3).

Nicholls and Wujek (2003) reviewed the biology of this common alga of mountain streams:

One of the most dramatic examples of a cold-water stenotherm is the mountainstream-dwelling chrysophyte Hydrurus foetidus. This macroscopic, brown, gelatinous, unpleasant-smelling alga is relatively abundant in both the eastern and western mountain streams of North America. The gelatinous envelope in which the cells are embedded is exceedingly tough and the plant frequently covers the entire surface of submerged rocks and has caused more than one hiker to lose his or her footing when crossing a stream. It normally begins to disappear when water temperatures rise much above $10^{\circ} \mathrm{C} \ldots$ Other requirements for this species apparently include low $\mathrm{pH}$ and bright sunlight.

Hydrurus foetidus often dominates the winter and spring algal communities of glacier-fed streams of the Swiss Alps, which exhibit unstable channels and wide seasonal fluctuations in flow, temperature, and turbidity (Hieber et al. 2001). Elsewhere, Kawecka (1990) reported that Hydrurus foetidus (along with Ulothrix zonata) dominated the algal communities of unregulated streams in a study of paired regulated and unregulated streams.

Sullivan Creek above Connor Creek. Diatoms, which were abundant, ranked second to Hydrurus foetidus in terms of total biomass, followed by the filamentous cyanobacterium 
Phormidium, which was frequent. The branched filamentous green alga Stigeoclonium and the filamentous cyanophyte Amphithrix were occasional components of the algal flora at this site.

Sullivan Creek below Quintonkon Creek. Diatoms were also abundant and ranked second to Hydrurus at this site. The filamentous green algae Zygnema sp. and Ulothrix zonata were abundant and frequent here and ranked third and fourth in biovolume, respectively. An increase in dominance by filamentous green alage generally parallels an increase in nutrient concentrations in streams (Wehr and Sheath 2003). The filamentous cyanophyte Hydrocoleum ranked fifth in biomass at this site.

Skyland Creek above Bear Creek. Hydrurus foetidus and diatoms were co-dominants at this site and ranked first and second, respectively, in terms of biomass. The filamentous green alga Ulothrix zonata, which was abundant, was the only other non-diatom species present at this site (Table 3).

\section{Diatoms (Table 4)}

The four major diatom species from Sullivan Creek and Skyland Creek are included in pollution tolerance classes 3 or 2 and are either sensitive to organic pollution or only somewhat tolerant of organic pollution (Table 4). None of the major diatom species are most tolerant of organic pollution (pollution tolerance class $=1$ ).

Sullivan Creek above Connor Creek. A very high value for the percent dominant species (Hannaea arculs) and low values for the number of species counted and the diversity index indicate moderate to severe stress at this site (Table 4). Since Hannaea arcus is a cold stenothermal diatom and an attached pioneer species that is sensitive to organic pollution, its dominance here is probably related to steep gradients, fast currents, cold temperatures, and/or low nutrient concentrations. Hannaea arcus is one of the most common diatom species in glacier- and snowmelt-fed streams of the Swiss Alps (Hieber et al. 2001). A high value for the pollution index and zero values for the siltation index and percent abnormal cells indicate that organic enrichment, sedimentation, and toxic metals did not affect the association of benthic diatoms at this site and that the stresses recorded here are probably natural in origin. The only 
other major diatom species at this site-Achnanthidium minutissimum-is also an attached pioneer species that is sensitive to organic loading.

Sullivan Creek below Quintonkon Creek. Although the equitability and diversity of diatom species improved at this site compared to the upstream site, diatom species richness remained low and still indicated moderate stress from natural causes. However, a significant decline in the pollution index occurred between the upstream site and this site (Table 4), which indicated a significant increase in organic loading. Although organic loading increased, the pollution index at this site remained above the threshold for minor impairment. However, the dominant diatom species here (Fragilaria vaucheriae) is somewhat tolerant of organic loading and the large percentage of this species indicated minor impaiment here.

A few teratological cells of Fragilaria vaucheriae and Hannaea arcus were also counted at this site. Abnormal diatom cells sometimes indicate elevated concentrations of heavy metals (McFarland et al. 1997). However, there are many other possible causes of abnomal diatom cells, including natural factors such as rapid population growth and crowding, silica depletion, low water temperatures, and low $\mathrm{pH}$. The araphid diatoms, which include $F$. vaucheriae and $H$. arcus, seem to be especially prone to producing teratological cells (McFarland et al. 1997). Given that populations of $F$. vaucheriae and $H$. arcus were very large and probably expanding at the time, and given the austere environmental conditions prevailing at this site, the minor stress indicated by a few abnormal cells in Sullivan Creek is likely natural in origin and not related to heavy metals. The two sites on Sullivan Creek shared $43 \%$ of their diatom associations, which indicates somewhat similar floras and minor environmental change.

Skyland Creek above Bear Creek. The dominant diatom at this site was Encyonema silesiacum, which is somewhat tolerant of organic pollution. A large percentage of this species indicated moderate impairment here (Table 4). The pollution index also indicated minor impaiment from organic loading. Diatom species richness, equitability, and diversity were also low and indicated minor impaiment. Two abnormal cells of Hannaea arcus were observed during the diatom proportional count, again probably the result of natural causes. 


\section{Modal Categories (Table 5)}

Several ecological attributes assigned by Stevenson and Van Dam et al. (1994) were selected from the diatom reports in the appendix and modal categories of these attributes were extracted to characterize water quality tendencies in Sullivan and Skyland Creeks (Table 5).

The majority of diatoms at both sites on Sullivan Creek were non-motile autotrophs that tolerate high concentrations of organics and indicate alkaline and fresh-brackish waters with continuously high dissolved oxygen. However, the percentage of diatoms in the "continuously high" category declined significantly from the upstream site to the downstream site, indicating a decline in the availability of dissolved oxygen. The modal categories for saprobity and trophic state each shifted two levels between the upstream and downstream sites, indicating significant increases in organic loading and concentrations of inorganic nutrients.

In Skyland Creek, the modal category for oxygen demand was "moderate", indicating even less available dissolved oxygen here than in lower Sullivan Creek. The modal category for saprobity in Skyland Creek was alpha-mesosaprobous, which is the same modal category that was recorded at the lower site on Sullivan Creek (Table 5). The alpha-mesosaprobous category indicates waters with $25-70 \%$ oxygen saturation and 4-13 mg/L BOD (Van Dam et al. 1994). 


\section{References}

APHA. 1998. Standard Methods for the Examination of Water and Wastewater. 20 ${ }^{\text {th }}$ Edition. American Public Health Association, Washington, D.C.

Bahls, L.L. 1979. Benthic diatom diversity as a measure of water quality. Proceedings of the Montana Academy of Sciences 38:1-6.

Bahls, L.L. 1993. Periphyton Bioassessment Methods for Montana Streams (revised). Montana Department of Health and Environmental Sciences, Helena.

Bahls, L.L., Bob Bukantis, and Steve Tralles. 1992. Benchmark Biology of Montana Reference Streams. Montana Department of Health and Environmental Sciences, Helena.

Barbour, M.T., J. Gerritsen, B.D. Snyder, and J.B. Stribling. 1999. Rapid Bioassessment Protocols for Use In Streams and Wadeable Rivers: Periphyton, Benthic Macroinvertebrates and Fish. Second Edition. EPA/841-B-99-002. U.S. Environmental Protection Agency, Office of Water, Washington, D.C.

Beaver, Janet. 1981. Apparent Ecological Characteristics of Some Common Freshwater Diatoms. Ontario Ministry of The Environment, Technical Support Section, Don Mills, Ontario.

Hieber, Maggi, C.T. Robinson, S. R. Rushforth, and Urs Uehlinger. 2001. Algal communities associated with different alpine stream types. Arctic, Antarctic, and Alpine Research 33(4):447-456.

Johansen, J.R. 1999. Diatoms of Aerial Habitats. Chapter 12 in Stoermer, E.F., and J.P. Smol (eds.), The Diatoms: Applications For the Environmental and Earth Sciences, Cambridge University Press, New York.

John, D.M., B.A. Whitton, and A.J. Brook (eds.). 2002. The Freshwater Algal Flora of the British Isles: An Identification Guide to Freshwater and Terrestrial Algae. Cambridge University

Karr, J.R., and D.R. Dudley. 1981. Ecological perspectives on water quality goals. Environmental Management 5:55-69.

Kawecka, B. 1990. The effect of flood-control regulation of a montane stream on the communities of sessile algae. Acta Hydrobiology 32:345-354.

Krammer, Kurt. 1997a. Die cymbelloiden Diatomeen: Eine Monographie der weltweit bekannten Taxa. Teil 1. Allgemeines and Encyonema Part. J. Cramer, Berlin.

Krammer, Kurt. 1997b. Die cymbelloiden Diatomeen: Eine Monographie der weltweit bekannten Taxa. Teil 2. Encyonema part., Encyonopsis and Cymbellopsis. J. Cramer, Berlin.

Krammer, Kurt. 2002. Cymbella. Volume 3 in Diatoms of Europe, Horst Lange-Bertalot, ed. A.R.G. Gantner Verlag K.G., Germany.

Krammer, K., and H. Lange-Bertalot. 1986. Bacillariophyceae, Part 2, Volume 1: Naviculaceae. In Ettl, H., J Gerloff, H. Heynig, and D. Mollenhauer (eds.), Freshwater Flora of Middle Europe. Gustav Fischer Publisher, New York.

Krammer, K., and H. Lange-Bertalot. 1988. Bacillariophyceae, Part 2, Volume 2: Bacillariaceae, Epithemiaceae, Surirellaceae. In Ettl, H., J. Gerloff, H. Heynig, and D. Mollenhauer (eds.), Freshwater Flora of Middle Europe. Gustav Fischer Publisher, New York. 
Krammer, K., and H. Lange-Bertalot. 1991 a. Bacillariophyceae, Part 2, Volume 3: Centrales, Fragilariaceae, Eunotiaceae. In Ettl, H., J. Gerloff, H. Heynig, and D. Mollenhauer (eds.), Freshwater Flora of Middle Europe. Gustav Fischer Publisher, Stuttgart.

Krammer, K., and H. Lange-Bertalot. $199 \mathrm{lb}$. Bacillariophyceae, Part 2, Volume 4: Achnanthaceae, Critical Supplement to Navicula (Lineolatae) and Gomphonema, Complete List of Literature for Volumes 1-4. In Ettl, H., G. Gartner, J. Gerloff, H. Heynig, and D. Mollenhauer (eds.), Freshwater Flora of Middle Europe. Gustav Fischer Publisher, Stuttgart.

Lange-Bertalot, Horst. 1979. Pollution tolerance of diatoms as a criterion for water quality estimation. Nova Hedwigia 64:285-304.

Lange-Bertalot, Horst. 1993. 85 new taxa and much more than 100 taxonomic clarifications supplementary to Susswasserflora von Mitteleuropa Vol. 2/1-4. J. Cramer, Berlin.

Lange-Bertalot, Horst. 1996. Rote Liste der limnischen Kieselalgen (Bacillariophyceae) Deutschlands. Schr.-R. f. Vegetationskde., H. 2S, pp. 633-677. BfN, Bonn-Bad Godesberg.

Lange-Bertalot, Horst. 2001. Navicula sensu stricto: 10 Genera Separated from Navicula sensu lato; Frustulia. Volume 2 in Diatoms of Europe, Horst Lange-Bertalot, ed. A.R.G. Gantner Verlag K.G., Germany.

Lowe, R.L. 1974. Environmental Requirements and Pollution Tolerance of Freshwater Diatoms. EPA-670/4-74-005. U.S. Environmental Protection Agency, National Environmental Research Center, Office of Research and Development, Cincinnati, Ohio.

McFarland, B.H., B.H. Hill, and W.T. Willingham. 1997. Abnormal Fragilaria spp. (Bacillariophyceae) In streams impacted by mine drainage. Journal of Freshwater Ecology 12(1):141-149.

Morales, E.A., and Marina Potapova. 2000. Third NAWQA Workshop on Harmonization of Algal Taxonomy, May 2000. Patrick Center for Environmental Research, The Academy of Natural Sciences, Philadelphia.

Nicholls, K.H., and D.E.Wujek. 2003. Chrysophycean Algae. Chapter 12 (pp. 471-509) in Wehr, J.D., and R.G. Sheath (eds.), Freshwater Algae of North America: Ecology and Classification. Academic Press, New York.

Palmer, C.M. 1969. A composite rating of algae tolerating organic pollution. Journal of Phycology 5:78-82.

Palmer, C.M. 1977. Algae and Water Pollution: An lllustrated Manual on the Identification, Significance, and Control of Algae in Water Supplies and in Polluted Water. EPA-600/9-77-036.

Plafkin, J.L., M.T. Barbour, K.D. Porter, S.K. Gross, and R.M. Hughes. 1989. Rapid Bioassessment Protocols for Use in Rivers and Streams: Benthic Macroinvertebrates and Fish. EPA 440-4-89-001.

Prescott, G.W. 1962. Algae of the Western Great Lakes Area. Wm. C. Brown Company, Dubuque, lowa.

Prescott, G.W. 1978. How to Know the Freshwater Algae. Third Edition. Wm. C. Brown Company Publishers, Dubuque, lowa.

Reichardt, Erwin. 1997. Taxonomische Revision des Artenkomplexes un Gomphonema pumilum (Bacillariophyta). Nova Hedwigia 65(1-4):99-129.

Reichardt, Erwin. 1999. Zur Revision der Gattung Gomphonema. A.R.G. Gantner Verlag, Distributed by Koeltz Scientific Books, Konigstein, Germany.

Renfro, H.B., and D.E. Feray. 1972. Geological Highway Map of the Northern Rocky Mountain Region. American Association of Petroleum Geologists, Tulsa, Oklahoma. 
Smith, G.M. 1950. The Fresh-Water Algae of The United States. McGraw-Hill Book Company, New York.

Stevenson, R.J., and Y. Pan. 1999. Assessing Environmental Conditions in Rivers and Streams with Diatoms. Chapter 2 in Stoermer, E.F., and J.P. Smol (eds.), The Diatoms: Applications For the Environmental and Earth Sciences, Cambridge University Press, New York.

Stewart, W.D.P., P. Rowell, and A.N. Rai. 1980. Symbiotic Nitrogen-Fixing Cyanobacteria. Pp. 239-277 in Stewart, W.D.P., and J. Gallo (eds.), Nitrogen Fixation, Academic Press, New York.

USDA. 1976. Climax Vegetation of Montana (map). U.S. Department of Agriculture, Soil Conservation Service, Cartographic Unit, Portland.

USEPA. 2000. Level 111 Ecoregions of the Continental United States (map). National Health and Environmental Effects Research Laboratory, U.S. Environmental Protection Agency, Corvallis, Oregon.

Van Dam, Herman, Adrienne Mertens, and Jos Sinkeldam. 1994. A coded checklist and ecological Indicator values of freshwater diatoms from The Netherlands. Netherlands Journal of Aquatic Ecology 28(1):117-133.

Weber, C.I. (ed.). 1973. Biological Field and Laboratory Methods for Measuring the Quality of Surface Waters and Effluents. EPA-670/4-73-00I. U.S. Environmental Protection Agency, National Environmental Research Center, Office of Research and Development, Cincinnati, Ohio.

Wehr, J.D., and R.G. Sheath. 2003. Freshwater Algae of North America: Ecology and Classification. Academic Press, New York.

Whittaker, R.H. 1952. A study of summer foliage insect communities in the Great Smoky Mountains. Ecological Monographs 22:1-44.

Woods, A.J., Omernik, J.M., Nesser, J.A., Shelden, J., and S.H. Azevedo. 1999. Ecoregions of Montana (color poster with map), U.S. Geological Survey, Reston, Virginia. 
Table 1. Location of periphyton sampling stations in the upper Flathead River TMDL planning area, 2002.

\begin{tabular}{lccccc}
\hline \multicolumn{1}{c}{ Station } & $\begin{array}{c}\text { MDEQ } \\
\text { Station } \\
\text { Code }\end{array}$ & $\begin{array}{c}\text { Hannaea } \\
\text { Sample } \\
\text { Number }\end{array}$ & Latitude & Longitude & $\begin{array}{c}\text { Sample } \\
\text { Date }\end{array}$ \\
\hline Sullivan Creek above Connor Creek & C08SULLC01 & $2655-01$ & $47-58.536$ & $113-40.122$ & $8 / 22 / 02$ \\
Sullivan Creek below Quintonkon Creek & C08SULLC02 & $2656-01$ & $48-1.668$ & $113-42.312$ & $8 / 22 / 02$ \\
Skyland Creek above Bear Creek & C08SKYLC01 & $2657-01$ & $48-17.574$ & $113-23.34$ & $8 / 23 / 02$ \\
\hline
\end{tabular}




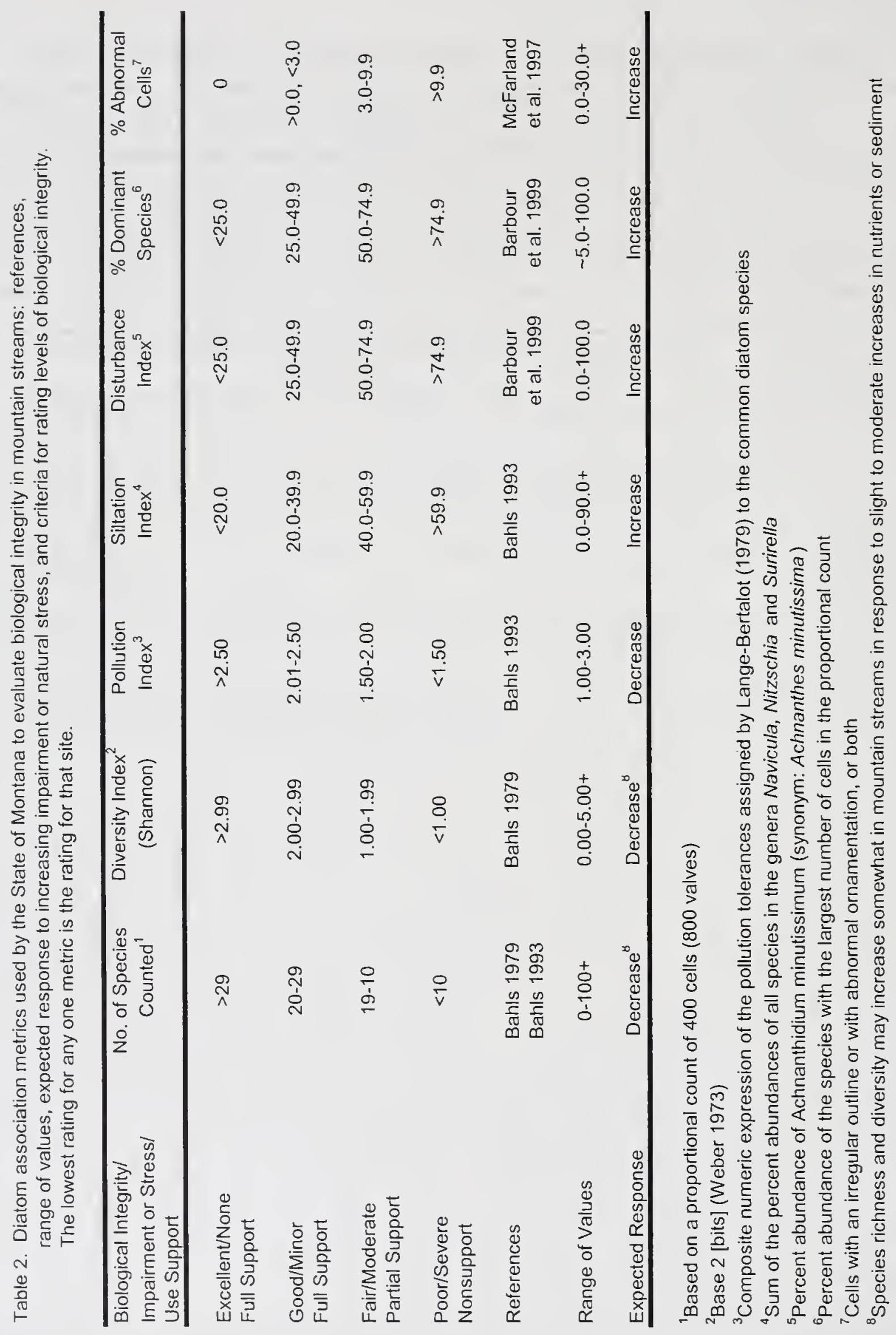


Table 3. Relative abundance of cells and ordinal rank by biovolume of diatoms (Division Bacillariophyta) and genera of non-diatom algae in periphyton samples collected from Sullivan Creek and Skyland Creek in 2002.

Taxa

Sullivan Creek above Connor Creek

Phormidium

\section{Chlorophyta}

Stigeoclonium

Ulothrix zonata

Zygnema

\section{Chrysophyta}

Hydrurus foetidus

Bacillariophyta abundant $\left(1^{\text {st }}\right)$

abundant $\left(2^{\text {nd }}\right)$ occasional $\left(5^{\text {th }}\right)$

frequent $\left(3^{\text {rd }}\right)$

$$
\text { occasional }\left(4^{\text {th }}\right)
$$

$$
\text { frequent }\left(4^{\text {th }}\right)
$$$$
\text { abundant }\left(3^{\text {rd }}\right)
$$

Skyland Creek above Bear Creek

\section{below Quintonkon Creek}

dominant $\left(1^{\text {st }}\right)$

abundant $\left(2^{\text {nd }}\right)$ abundant $\left(3^{\text {rd }}\right)$

dominant $\left(1^{\text {st }}\right)$

dominant $\left(2^{\text {nd }}\right)$ 
Table 4. Percent abundance of major diatom species ${ }^{1}$ and values of selected diatom association metrics for periphyton samples collected from Sullivan Creek and Skyland Creek in 2002. Underlined values indicate minor stress; bold values indicate moderate stress; underlined and bold values indicate severe stress; all other values indicate no stress and full support of aquatic life uses when compared to criteria for mountain streams in Table 2. Stress may be natural or anthropogenic (see text)

\begin{tabular}{lcccc}
\hline \multicolumn{1}{c}{ Species/Metric } & PTC $^{2}$ & $\begin{array}{c}\text { Sullivan Creek } \\
\text { above Connor Creek }\end{array}$ & $\begin{array}{c}\text { Sullivan Creek below } \\
\text { Quintonkon Creek }\end{array}$ & $\begin{array}{c}\text { Skyland Creek } \\
\text { above Bear Creek }\end{array}$ \\
\hline Achnanthidium minutissimum & 3 & 6.21 & 14.32 & 7.11 \\
Encyonema silesiacum & 2 & 0.48 & 2.58 & 54.62 \\
Fragilaria vaucheriae & 2 & 1.07 & 38.62 & 4.15 \\
Hannaea arcus & 3 & 80.79 & 28.87 & 19.08 \\
Number of Species Counted & & 15 & 17 & $\underline{23}$ \\
Shannon Species Diversity & 1.27 & $\underline{2.49}$ & $\underline{2.32}$ \\
Pollution Index & 2.94 & 2.58 & 3.55 \\
Siltation Index & 0.00 & 0.23 & 7.11 \\
Disturbance Index & 6.21 & $\underline{38.62}$ & $\mathbf{5 4 . 6 2}$ \\
Percent Dominant Species & $\underline{80.79}$ & $\underline{0.59}$ & $\underline{0.24}$ \\
Percent Abnormal Cells & 0.00 & 42.68 & \\
Similarity Index & & & \\
\hline
\end{tabular}

${ }^{1}$ A major diatom species accounts for $5.0 \%$ or more of the cells at one or more stations in a sample set.

${ }^{2}$ (Organic) Pollution Tolerance Class (Lange-Bertalot 1979): $1=$ most tolerant; $2=$ tolerant; $3=$ sensitive.

${ }^{3}$ Percent Community Similarity (Whittaker 1952) when compared to the diatom assemblage at the adjacent upstream station. 
Table 5. Modal categories for selected ecological attributes of diatom species in Sullivan Creek and. Skyland Creek in 2002.

\begin{tabular}{|c|c|c|c|}
\hline Ecological Attribute & $\begin{array}{c}\text { Sullivan Creek } \\
\text { above Connor Creek }\end{array}$ & $\begin{array}{c}\text { Sullivan Creek } \\
\text { below Quintonkon Creek }\end{array}$ & $\begin{array}{c}\text { Skyland Creek } \\
\text { above Bear Creek }\end{array}$ \\
\hline Motility ${ }^{1}$ & $\begin{array}{l}\text { Not } \\
\text { Motile }\end{array}$ & $\begin{array}{l}\text { Not } \\
\text { Motile }\end{array}$ & $\begin{array}{l}\text { Variable } \\
\text { Motility }\end{array}$ \\
\hline $\mathrm{pH}^{2}$ & Alkaliphilous & Alkaliphilous & Circumneutral \\
\hline Salinity ${ }^{2}$ & $\begin{array}{l}\text { Fresh- } \\
\text { Brackish }\end{array}$ & $\begin{array}{l}\text { Fresh- } \\
\text { Brackish }\end{array}$ & $\begin{array}{l}\text { Fresh- } \\
\text { Brackish }\end{array}$ \\
\hline Nitrogen Uptake ${ }^{2}$ & $\begin{array}{l}\text { Autotrophs } \\
\text { (tolerate high } \\
\text { organics) }\end{array}$ & $\begin{array}{l}\text { Autotrophs } \\
\text { (tolerate high } \\
\text { organics) }\end{array}$ & $\begin{array}{l}\text { Autotrophs } \\
\text { (tolerate high } \\
\text { organics) }\end{array}$ \\
\hline Oxygen Demand ${ }^{2}$ & Continuously High ( $91 \%)$ & $\begin{array}{c}\text { Continuously High (52\%) } \\
\text { Moderate }(42 \%)\end{array}$ & $\begin{array}{c}\text { Moderate (62\%) } \\
\text { Continuously High (34\%) }\end{array}$ \\
\hline Saprobity ${ }^{2}$ & Oligosaprobous & alpha-Mesosaprobous & alpha-Mesosaprobous \\
\hline Trophic State ${ }^{2}$ & Mesotraphentic & Eutraphentic & Variable \\
\hline
\end{tabular}

${ }^{1}$ Dr. R. Jan Stevenson, Michigan State University, digital communication.

${ }^{2}$ Van Dam et al. 1994 
-

- 